\title{
Pre-germination Treatments, Quality of Light and Temperature on Syagrus coronata (Mart.) Becc. Seeds Germination
}

\author{
Jorge M. P. Porto ${ }^{1}$, Viviane L. Oliveira ${ }^{1}$, Michele L. Souza ${ }^{1}$, Rafaeli A. V. Souza ${ }^{1}$, \\ Adriana Soares ${ }^{1} \&$ Francyane T. Braga ${ }^{1}$ \\ ${ }^{1}$ Departamento de Educação, Universidade do Estado da Bahia, Paulo Afonso, Bahia, Brazil \\ Correspondence: Francyane T. Braga, Departamento de Educação, Universidade do Estado da Bahia, Rua da \\ Gangorra, 503, Paulo Afonso, BA, 48608-240, Brazil. Tel: 55-(75)-99210-3432. E-mail: ftbraga@yahoo.com.br
}

$\begin{array}{lc}\text { Received: January 29, } 2018 \quad \text { Accepted: March 1, } 2018 \quad \text { Online Published: April 15, } 2018 \\ \text { doi:10.5539/jas.v10n5p268 } & \text { URL: https://doi.org/10.5539/jas.v10n5p268 }\end{array}$

The research is financed by Fundação de Amparo à Pesquisa do Estado da Bahia (FAPESB).

\begin{abstract}
Studies show that most species of palm trees present seed dormancy. This characteristic hinders the production of seedlings, due to the long period for germination and the unevenness of the seedlings. The specie Syagrus coronata, despite being widely used as food and economic resources, presents also seed dormancy, which hinders its propagation. Thus, this work aimed at evaluating the germination of $S$. coronata seeds using different methods of dormancy breaking and also, under different qualities of light and temperature. To do so, the seed endocarps were scarified by friction, puncture and complete removal of the endocarp, and the pre-soaking of seeds at different concentrations $\left(50,100,200\right.$ and $\left.400 \mathrm{mg} \mathrm{L}^{-1}\right)$ of gibberellic acid $\left(\mathrm{GA}_{3}\right)$ and indolebutyric acid (IBA). We also evaluated the effect of germination in seeds exposed to different conditions of light (white, red, far red, blue and dark) and to different temperatures $\left(25,30,35\right.$ and $\left.20-30{ }^{\circ} \mathrm{C}\right)$. The data show that the act of rubbing the endocarp optimizes the seed germination process. Solutions containing growth regulators in the pre-soaking of seeds have a negative impact on germination. And the absence of light and the constant temperature of $25^{\circ} \mathrm{C}$ are the most suitable for germination. The results indicate that $S$. coronata seeds have physical dormancy, and, despite obtaining greater germination in the dark, they are neutral photoblastic.
\end{abstract}

Keywords: Arecaceae, dormancy, scarification, semiarid region, growth regulators

\section{Introduction}

Syagrus coronata (Mart.) Becc., a palm tree native to Brazil, belongs to the family Arecaceae and occurs in many states in the semiarid region of the Brazilian northeast (Lorenzi, 2010). The species is widely used for human and cattle nutrition, civil construction, handcrafting, as medication and fuel, by extracting oil from their seeds (Rufino et al., 2008).

$S$. coronata has sexual reproduction. Its germination is affected by dormancy, which makes its development slow and irregular (Drumond, 2007), hindering the production of seedlings in large scale. In general, low germination rate in palm trees are associated with seed dormancy, which happens due to impermeability to water, embryonic immaturity, presence of chemical inhibitors, mechanical resistance of the endocarp or the combination of all these factors (Bewley \& Black, 1994).

In order to break seed dormancy, pre-germination treatments have been used in different species of family Arecaceae, such as removal and scarification of the endocarp and the use of growth regulators (Luz et al., 2008; Pérez et al., 2008; Dewir et al., 2011; Soares et al., 2012; Oliveira et al., 2013; Neto et al., 2014; Pêgo \& Grossi, 2016). For S. coronata, Carvalho et al. (2005) did not report any positive effect on germination after removing the seed endocarp, however, the germination rate was higher when they were soaked in solutions with gibberellic acid $\left(\mathrm{GA}_{3}\right)$. This effect was also observed by Medeiros et al. (2015a), and Medeiros et al. (2015b). Despite some studies for this species, the use of these methods together can result in the reduction of the time and standardization of the seedlings produced, which will contribute to the inclusion of this potentially productive species into programs of plant production and improvement. 
In addition to dormancy, there are other variables that affect seed germination, such as light and temperature. Regarding family Arecaceae, temperature and light variation have already been studied by different authors, which determined what conditions result in the best germination potential for these species (Pérez et al., 2008; Pimenta et al., 2010; Ribeiro et al., 2011; Sanjeewani et al., 2013; Rodrigues et al., 2014).

In view of this, this work had as aimed to test different methods of breaking dormancy and to verify the influence of light and temperature on the germination of $S$. coronata seeds.

\section{Material and Methods}

The fruits of $S$. coronata were harvested from an area of 1.2 ha located in Juá, in the city of Paulo Afonso-BA $\left(09^{\circ} 26^{\prime} 48.8^{\prime \prime} \mathrm{S}\right.$ and $38^{\circ} 25^{\prime} 53.1^{\prime \prime} \mathrm{W}$ Gr., altitude $428 \mathrm{~m}$-Datum WGS 84), inserted in the Ecoregion Raso da Catarina, BA.

In laboratory, the fruits were immersed in water for 24 hours and their endocarps were manually removed and placed to dry at room environment for 48 hours in the shadow.

The seeds were desinfested in $70 \%$ ethanol for 30 seconds and in $2 \%$ sodium hypochlorite for 10 minutes. Afterwards, the seeds were rinsed in autoclaved distilled water to remove any residues of disinfesting solutions.

In the first experiment, the endocarps were removed with the aid of a hammer, before conditioning them to different qualities of light: white; red; far red; blue; and dark. For these conditions, trays with the seeds were covered with two sheets of transparent, red, overlaid red and blue, and blue cellophane paper, and aluminum foil, respectively (Yamashita et al., 2011). The treatments remained in the lab, exposed to natural light and at $25^{\circ} \mathrm{C}$.

In the second experiment, related to dormancy breaking, we used methods of mechanic scarification, which consisted of the following treatments: manual friction of the seeds with a $\# 80$ wood sandpaper in the area of the endocarp pore; puncture of the endocarp in the area of the endocarp pore with the aid of a mini rectifier; complete removal of the endocarp; and, seeds with intact endocarp (control treatment).

In the third treatment, $S$. coronata seeds previously sanded were used, because they had the best results in the experiment to break dormancy. The seeds were soaked in solutions with growth regulators for 48 hours, and the treatments consisted of gibberellic acid $\left(\mathrm{GA}_{3}\right)$ and indolebutyric acid (IBA) at concentrations of 50, 100, 200 and $400 \mathrm{~m} \mathrm{~L}^{-1}$. For the control treatment, only distilled water was used.

In the fourth experiment, the variation of temperature for germination was tested. Previously sanded seeds were placed under the following conditions: $25^{\circ} \mathrm{C}, 30^{\circ} \mathrm{C}, 35^{\circ} \mathrm{C}$ and variable temperatures $\left(20-30{ }^{\circ} \mathrm{C}\right)$.

In all experiments, the seeds were pre-soaked in distilled water for 24 hours, except for the third experiment. Afterwards, they were wrapped in two sheets of paper towels, placed on plastic trays and humidified daily with distilled water, at the proportion equivalent to 2.5 the weight of the paper towel.

The seeds from the second, third and fourth experiments were conditioned in a germination chamber (B.O.D.). The treatments were kept at the absence of light, in accordance with the parameter obtained from the first experiment, which tested different qualities of light and absence of light.

The design was fully randomized. Each tray had four repetitions with 25 seeds, so each treatment had 60 seeds. The evaluations were carried out every seven days, for 72 days.

For all experiments, the variables assessed were: percentage of germination, determined by the expression proposed in the Rules for Seed Analysis (Ministério da Agricultura, Pecuária e Abastecimento, 2009): G(\%)= NG x 100 / NT; where G(\%) = percentage of germinated seeds, NG = number of germinated seeds and NT = total number of seeds placed to germinate; and germination speed rate (GSI), calculated by the methodology proposed by Maguire $(1962)$ : $\mathrm{GSI}=(\mathrm{G} 1 / \mathrm{N} 1)+(\mathrm{G} 2 / \mathrm{N} 2)+\ldots(\mathrm{Gn} / \mathrm{Nn})$, where, GSI = germination speed rate, G1, $\mathrm{G} 2, \ldots \mathrm{Gn}=$ number of germinated seeds in the first count, second count and last count, and $\mathrm{N} 1, \mathrm{~N} 2, \ldots \mathrm{Nn}=$ number of days elapsed from seeding to the first, second and last count.

The data were submitted to analysis of variance and the means were compared by Tukey test at $5 \%$ of probability for qualitative data. As for quantitative data, we used polynomial progression. The analyses were carried out with the aid of software Sisvar 5.3 (Ferreira, 2011).

\section{Results and Discussion}

The presence of light, regardless of quality, had a negative impact on the germination process of the species. The dark condition stood out in both the germination percentage and the GSI (Figures 1A and 1B). Among the treatments in the presence of light, the red had a greater percentage of seeds germination, when compared to the far-red light. There was no statistic difference to the other qualities of light. Regarding GSI, red was also the best, 
followed by blue light and far-red, and being statistically different from the white light. Given these results, the species can be characterized as neutral photoblastic, because, in addition to having greater germination capacity in the dark, the seeds also germinate in the presence of light.
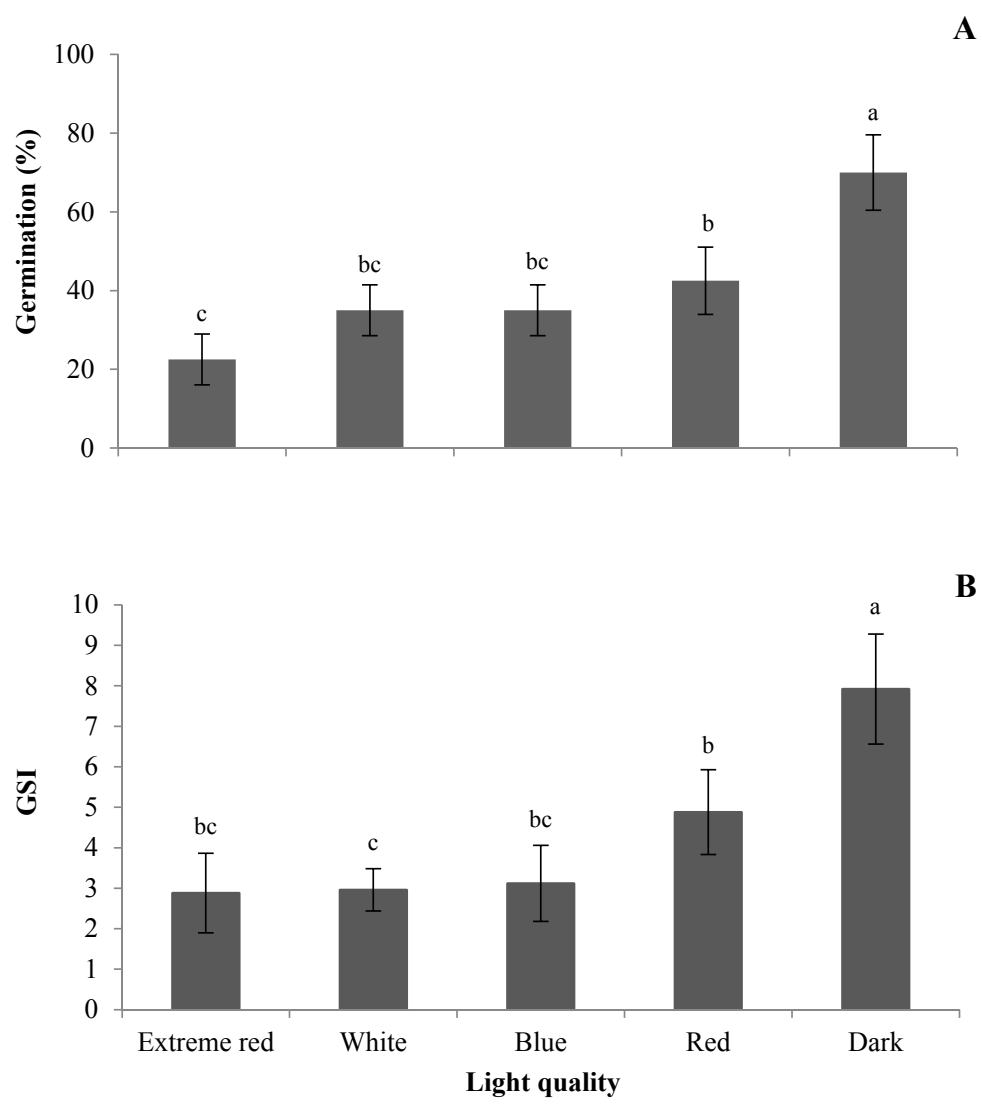

Figure 1. Percentage of germination (A) and germination speed index (GSI) (B) of S. coronata seeds submitted to different light qualities

This condition of neutral photoblastism is not a rule for family Arecaceae, because Sanjeewani et al. (2013) observed that Livistona rotundifolia (Lam.) Mart, a species that also belongs to this family, only germinated in the absence of light, after 30 days of incubation. Other results were found for the same family by Ribeiro et al. (2011), when they established Butia capitate (Mart.) Becc. embryos in vitro. The authors did not observe any significant effect among light and dark conditions over the elongation of the embryos, which suggests that the species is neutral photoblastic. Similar results were also found by Pérez et al. (2008), in which Pritchardia remota (Kuntze) Becc. seeds, when placed under light and dark conditions, had 90\% and 91\% of germination, respectively.

Regarding the germination tests using different scarification methods, all the treatments were superior to the control treatment. The exception was only the endocarp puncture method, which presented a smaller percentage. This behavior may have been due to the injury caused to the embryo when puncturing the endocarp, damaging its germination. Therefore, it is possible to determine that $S$. coronata seeds have physical dormancy (Figure $2 \mathrm{~A}$ ) The total or partial removal of the seed endocarp had a positive effect on germination and, among the scarification methods used in this study, endocarp sanded part had the best result For GSI, the sanded seeds did not differ from those without endocarp, and both treatments had higher values than control treatment (Figure 2B). 

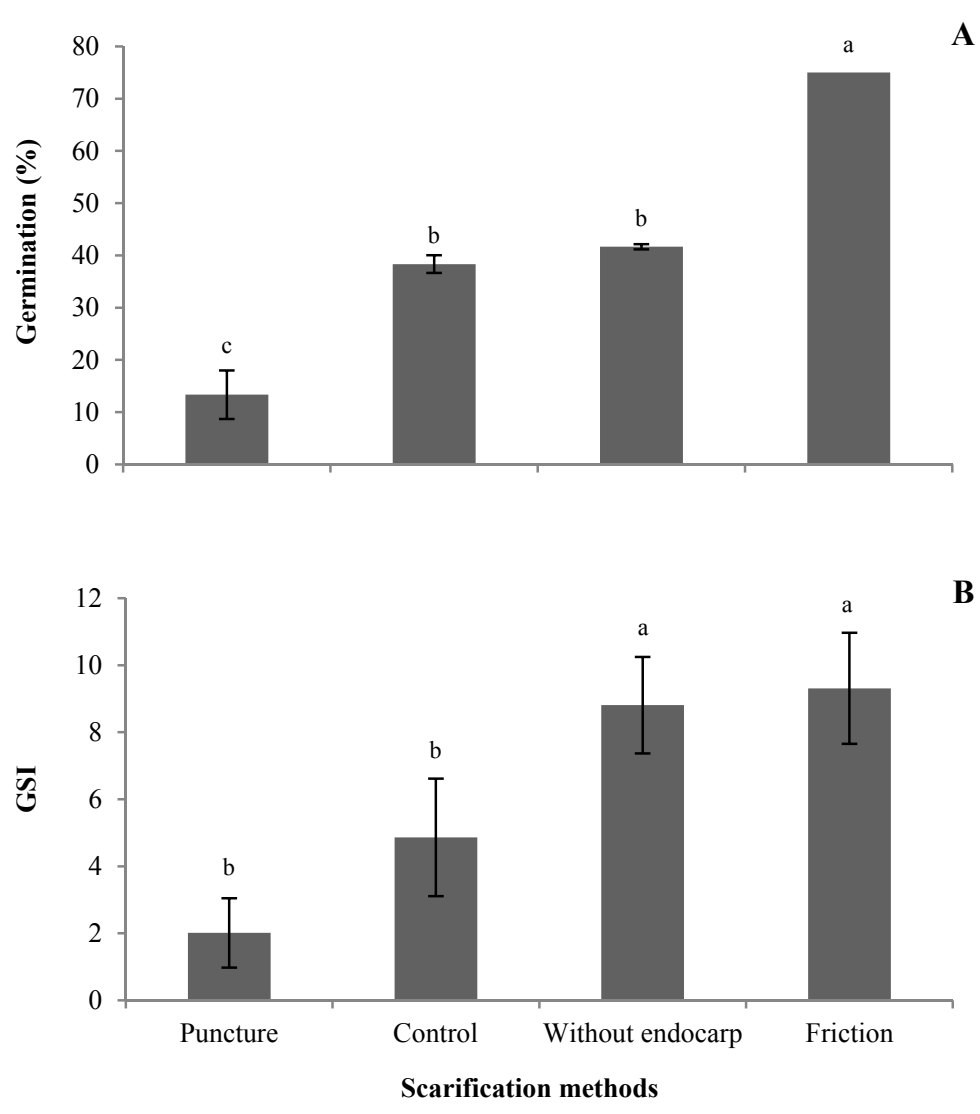

Figure 2. Percentage of germination (A) and germination speed index (GSI) (B) of S. coronata seeds submitted to different scarification methods

Carvalho et al. (2005) observed that removing the endocarp did not influence germination and GSI of $S$. coronata, which is a different result from this study. The same authors also observed that seeds without endocarp immersed in water for different periods caused a deterioration of the tissues, which suggests that the endocarp works as a protection for the seed. However, as to the effect of removing the endocarp on germination, Pérez et al. (2008) affirm that removing the endocarp accelerates the soaking process of the seed, which results in higher germination rates, when compared to seeds with endocarp. The authors observed that there was an increase of $39.5 \%$ in fresh mass of Pritchardia remota Becc (Arecaceae) seeds, while seeds with endocarp increased in 13\% only, after 336 hours of soaking. Neto et al. (2014) also observed better results in germination and GSI for Acrocomia aculeate (Jacq.) Loddiges ex Mart.) (Arecaceae) after the endocarp removal from the seeds, which proves the efficiency of this scarification method. Dewir et al. (2011) observed a similar effect when they scarified seeds of Thrinax morrisii H. Wendl (Arecaceae), which had a significant increase in percentage of germination and GSI of sanded seeds, when compared with those with intact endocarp (control). In contrast with the results in this work, Luz et al. (2008), when sanding Rhapis excelsa (Thunberg) Henry et. Rehder seeds, a species that also belongs to family Arecaceae, observed that this scarification method did not influence the emergence of the seedlings and obtained results similar to the control treatment. The authors also noticed that the seeds had the same behavior to emergence speed rate.

The use of growth regulators $\mathrm{GA}_{3}$ and IBA at the concentrations used in this study was not enough to influence the germination of $S$. coronata seeds, and there was no significant difference among the treatments. The 48 -hours period of soak of the seeds and the regulators concentration (50,100, 200, and $\left.400 \mathrm{mg} \mathrm{L}^{-1}\right)$ used in this work may have been negative factors for its germination, because, Carvalho et al. (2005) verified that $S$. coronata seeds soaked for 24 hours had a decrease in germination, as the concentration of $\mathrm{GA}_{3}$ increased. However, the 12-hour period soaked in a $\mathrm{GA}_{3}$ solution at $1,000 \mathrm{mg} \mathrm{L}^{-1}$ doubled the percentage of germination, when compared to seeds soaked in solutions without the regulator. Medeiros et al. (2015b) noticed, for the same species, a positive influence of the use of regulators when the seeds were soaked for 24 hours into $0.3 \mathrm{nM}$ of $\mathrm{GA}_{3}$. 
Medeiros et al. (2015a) also noticed $100 \%$ of germination in isolated S. coronata embryos, cultivated in culture media with 7.2-14.4 $\mu \mathrm{M}$ of $\mathrm{GA}_{3}$. Gibberellins mobilize reserves by synthesizing hydrolytic enzymes, which degrade starch and proteins, and weaken the layers of the endosperm around the seed embryos of certain species, promoting their growth (Bewley \& Black, 1994). This fact may indicate that $S$. coronata seeds need enough levels of phytohormones to optimize germination.

Figure 3 shows that the increase in concentration for both regulators caused a decrease in GSI. Carvalho et al. (2005) also observed that the increasing of this growth regulator also reduced GSI in seeds soaked for 24 hours. The seeds with partially sanded endocarps, as in this work, did not optimize the germination process after soaking them in solution with the exogenous hormone. Scarifying the seeds before exposing them to growth regulators was also tested by Pêgo and Grossi (2016), when they submitted Dypsis lutescens (H. Wendl.) Beentje \& J. Dransf (Arecaceae) seeds to these conditions and also noticed that scarification does not influence the germination of seeds soaked in solutions with $\mathrm{GA}_{3}$.

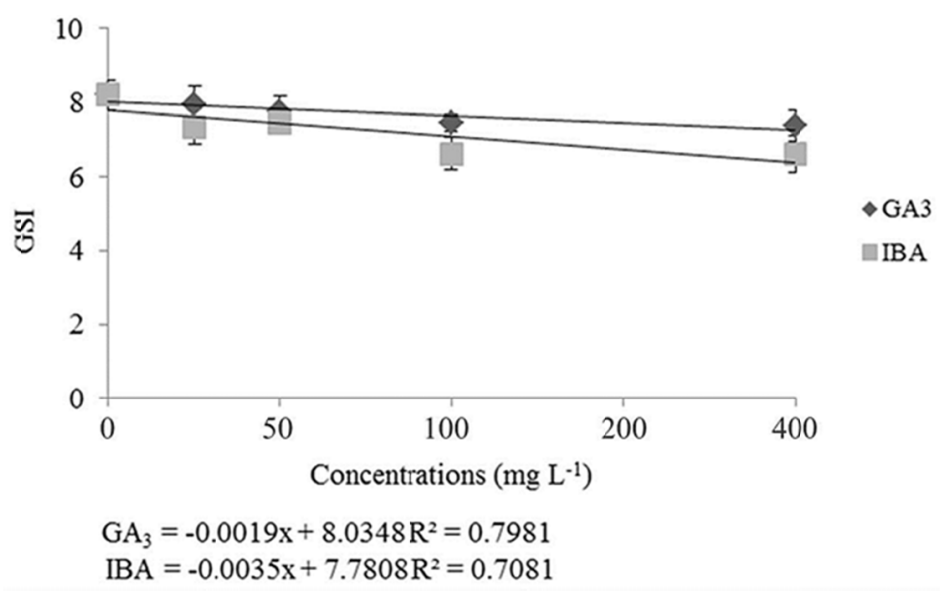

Figure 3. Germination speed index (GSI) of S. coronata seeds submitted to pre-soaking at different concentrations of giberelic acid $\left(\mathrm{GA}_{3}\right)$ and indolebutyric acid (IBA)

As in this work, Soares et al. (2012), while studying macaw palm (Acrocomia aculeate (Jacq.) Lodd. Ex Martius), a species from the same family as $S$. coronata, observed that different concentrations of $\mathrm{GA}_{3}$ did not influence germination. However, Ribeiro et al. (2011) observed that applying 2,000 $\mathrm{mg} \mathrm{L}^{-1}$ of $\mathrm{GA}_{3}$ favored germination, as it was also reported by Oliveira et al. (2013), for the same species.

Growth regulators affect seed germination and dormancy because they act upon different tissues (Idu, 2000). According to Cline (2000), IBA is widely used in these cases, because they induce root formation by breaking apical root dormancy. However, in this work, IBA did not have a positive effect on germination.

Seeds conditioned to germination at different temperatures presented significant statistical differences between treatments. The greatest germination rate occurred at constant temperature of $25^{\circ} \mathrm{C}$, followed by the treatment at variable temperatures $\left(20-30{ }^{\circ} \mathrm{C}\right)$. As temperature raised to 30 or $35^{\circ} \mathrm{C}$, there was a reduction of nearly $50 \%$ in germination, when compared to $25^{\circ} \mathrm{C}$ (Figure 4AB). As for GSI, temperature $35^{\circ} \mathrm{C}$ was the least responsive and the highest rate was also observed at $25^{\circ} \mathrm{C}$. 


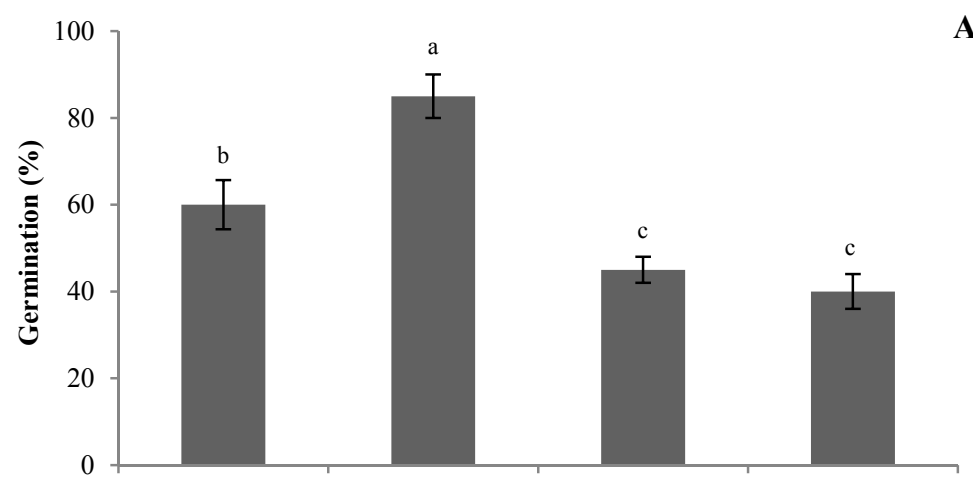

A

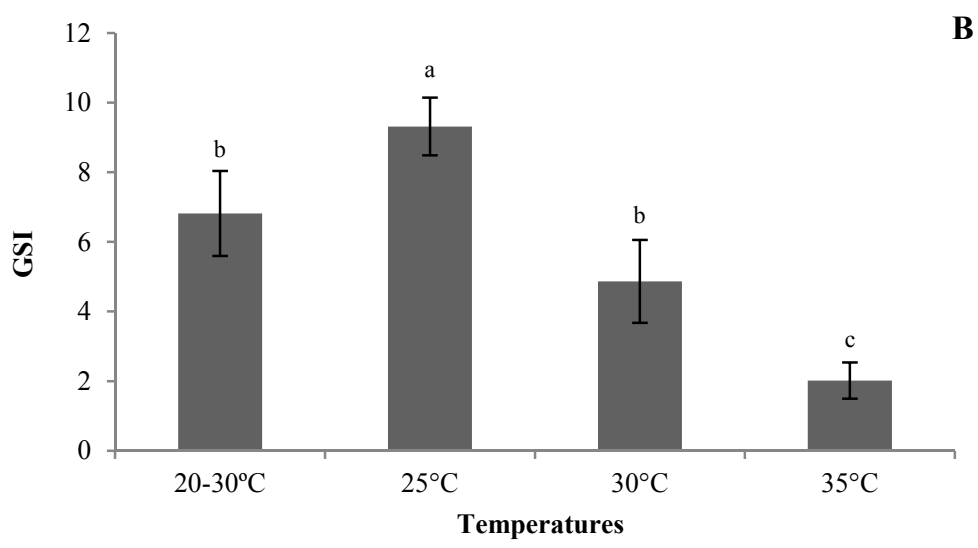

Figure 4. Effect of temperature on germination (A) and germination speed index (GSI) (B) of S. coronata seeds

Temperatures that favor seed germination vary according to the species. For different palm tree species, the most adequate temperatures for germination have been determined, such as $25{ }^{\circ} \mathrm{C}$ for Copernica prunifera (Reis, Bezerra, Gonçalves, Pereira, \& Freitas, 2010), $30{ }^{\circ} \mathrm{C}$ for Oenocarpus minor Mart. (Silva, Cesarino, Lima, Pantoja, \& Môro, 2006) and $35{ }^{\circ} \mathrm{C}$ for Thrinax parviflora Swartz (Pivetta et al., 2005). There are also other species that may have better results at varied temperatures, such as $25-30{ }^{\circ} \mathrm{C}$ for Dypsis decaryi Beentje \& $\mathrm{J}$. Dransf. (Luz et al., 2008).

Among the species of family Arecaceae, Rodrigues et al. (2014), while studying the species Bactris maraja Mart., observed that seeds kept at variable temperatures $\left(26-40{ }^{\circ} \mathrm{C}\right)$ germinated more and had greater GSI when compared to those kept at $20,25,30,35$ or $40^{\circ} \mathrm{C}$. A similar result was also obtained by Pimenta et al. (2010), who observed that Phoenix canariensis hort. ex Chabaud seeds were more responsive when germinated under variable temperatures of $20-30{ }^{\circ} \mathrm{C}$ or $25-35{ }^{\circ} \mathrm{C}$, as well as GSI. S. coronata seeds germinated well in the treatment in which the temperature varied between 20 and $30^{\circ} \mathrm{C}$, however, the constant temperature of $25^{\circ} \mathrm{C}$ was the most sensitive.

Our results are of great importance for the production of $S$. coronata seedlings, since they demonstrate that the pre-germination methods significantly increase the percentage of germination of the seeds. In view of the mechanical dormancy, we recommend sanding the seeds around the endocarp pore before seeding. Although the seeds showed neutral photoblastism, there are higher germination rates in the absence of light. The temperature of $25{ }^{\circ} \mathrm{C}$ has more effect on the germination of previously sanded seeds. And, in relation to the use of GA3 and IBA, we suggest new tests to determine the best concentration of these growth regulators and the best period of exposure of the seeds in these solutions that further favors the germination process of $S$. coronata.

\section{Acknowledgements}

To Fundação de Amparo à Pesquisa do Estado da Bahia (FAPESB), Coordenação de Aperfeiçoamento de Pessoal de Nível Superior (CAPES) and Conselho Nacional de Desenvolvimento Científico e Tecnológico (CNPq), for the financial support. 


\section{References}

Bewley, J. D., \& Black, M. (1994). Seeds: Physiology of development and germination (2nd ed.). New York, NY: Plenum Press. https://doi.org/10.1017/S0960258500002713

Carvalho, N. O. S., Pelacani, C. R., Rodrigues, M. O. S., \& Crepaldi, I. C. (2005). Uso de substâncias reguladoras e não-específicas na germinação de sementes de licuri (Syagrus coronata (Mart.) Becc). Sitientibus, 5(1), 28-32.

Cline, M. G. (2000). Execution of the auxin replacement apical dominance experiment in temperate woody species. American Journal of Botany, 87(2), 182-190. https://doi.org/10.2307/2656904

Dewir, Y. H., El-Mahrouk, M. E., \& Naidoo, Y. (2011). Effects of some mechanical and chemical treatments on seed germination of Sabal palmetto and Thrinax morrisii palms. Australian Journal of Crop Science, 5(3), 248-253. Retrieved from http://search.informit.com.au/documentSummary;dn=279508497268144;res= IELHSS

Drumond, M. A. (2007). Licuri Syagrus coronata (Mart.) Becc. Petrolina, PE: Embrapa Semiárido. Retrieved from http://ainfo.cnptia.embrapa.br/digital/bitstream/CPATSA/36697/1/SDC199.pdf

Ferreira, D. F. (2011). Sisvar: A computer statistical analysis system. Ciência e Agrotecnologia, 35, 1039-1042. https://doi.org/10.1590/S1413-70542011000600001

Idu, M. C. A. (2007). Hormonal effect on germination and seed ling development of Hura crepitans seeds. Asian Journalof Plant Science, 6, 696-699. https://doi.org/10.3923/ajps.2007.696.699

Lorenzi, H. (2010). Flora Brasileira: Arecaceae (palmeiras). São Paulo, SP: Plantarum.

Luz, P. B., Pimenta, R. S., Pizetta, P. U. C., Castro, A., \& Pivetta, K. F. L. (2008). Germinação de sementes de Dypsis decaryi (Jum.) Beentje \& J. Dransf. (Arecaceae). Ciência e Agrotecnologia, 32(5), 1461-1466. https://doi.org/10.1590/S1413-70542008000500016

Luz, P. B., Tavares, A. R., Paiva, P. D. O., Aguiar, F. F. A., \& Kanashiro, S. (2008). Germinação de sementes de palmeira-ráfia: Efeito de tratamentos pré-germinativos. Revista Árvore, 32(5), 793-798. https://doi.org/ $10.1590 / \mathrm{S} 0100-67622008000500002$

Maguire, J. D. (1962). Speed of germination-aid in selection and evaluation for seedling emergence and vigor. Crop Science, 2(1), 176-177. https://doi.org/10.2135/cropsci1962.0011183X000200020033x

Medeiros, M. J., Oliveira, D. S., Oliveira, M. T., Willadino, L., Houllou, L., \& Santos, M. G. (2015a). Ecophysiological, anatomical and biochemical aspects of in vitro culture of zygotic Syagrus coronata embryos and of young plants under drought stress. Trees, 29, 1219-1233. https://doi.org/10.1007/ s00468-015-1202-7

Medeiros, M. J., Oliveira, M. T., Willadino, L., \& Santos, M. G. (2015b). Overcoming seed dormancy using gibberellic acid and the performance of young Syagrus coronata plants under severe drought stress and recovery. Plant Physiology and Biochemistry, 97, 278-286. https://doi.org/10.1016/j.plaphy.2015.10.008

Ministério da Agricultura, Pecuária e Abastecimento. (2009). Regras para análise de sementes. Brasília, DF: Mapa/ACS.

Neto, A. R., Silva, F. G., Sales, J. F., Reis, E. F., Silva, L. Q., \& Campos, R. C. (2014). Dormancy breaking in macaw palm [Acrocomia aculeata (Jacq.) Loddiges ex Mart.] seeds. Acta Scientiarum. Agronomy, 36(1), 43-50. https://doi.org/10.4025/actasciagron.v36i1.13220

Oliveira, T. G. S., Rodrigues Junior, A. G., Souza, P. P., \& Ribeiro, L. M. (2013). Use of phytoregulators in overcoming macaw palm seed dormancy. Acta Scientiarum. Agronomy, 35, 505-511. https://doi.org/ 10.4025/actasciagron.v35i4.16385

Pego, R. G., \& Grossi, J. A. S. (2016). Biometry of fruits and seeds, dormancy and substrates in seeds germination of Dypsis lutescens. Ornamental Horticulture, 22(2), 215-220. https://doi.org/10.14295/ oh.v22i 2.885

Pérez, H. E., Criley, R. A., \& Baskin, C. C. (2008). Promoting germination in dormant seeds of Pritchardia remota (Kuntze) Beck., an endangered palm endemic to Hawai'i. Natural Areas Journal, 28, 251-260. https://doi.org/10.3375/0885-8608(2008)28[251:PGIDSO]2.0.CO;2 
Pimenta, R. S., Luz, P. B., Pivetta, K. F. L., Castro, A., \& Pizetta, P. U. C. (2010). Efeito da maturação e temperatura na germinação de sementes de Phoenix canariensis hort. Ex Chabaud - Arecaceae. Revista Árvore, 34(1), 31-38. https://doi.org/10.1590/S0100-67622010000100004

Pivetta, K. F. L., Casali, L. P., Cintra, G. S., Pedrinho, D. R., Pizetta, P. U. C., Pimenta, R. S., Penariol, A. P., \& Mattiuz, C. F. M. (2005). Efeito da temperatura e do armazenamento na germinação de sementes de Thrinax parviflora Swartz. (Arecaceae). Cientifica, 33(2), 178-184. https://doi.org/10.15361/1984-5529.2005v33n2 p178+-+184

Reis, R. G. E., Bezerra, A. M. E., Gonçalves, N. R., Pereira, M. S., \& Freitas, J. B. S. (2010). Biometria e efeito da temperatura e tamanho das sementes na protrusão do pecíolo cotiledonar de carnaúba. Revista Ciência Agronômica, 41(1), 81-86. https://doi.org/10.5935/1806-6690.20100011

Ribeiro, L. M., Neves, S. C., Silva, P. O., \& Andrade, I. G. (2011). Germinação de embriões zigóticos e desenvolvimento in vitro de coquinho-azedo. Revista Ceres, 58(2), 133-139. https://doi.org/10.1590/ S0034-737X2011000200001

Rodrigues, J. K., Mendonça, M. S., \& Gentil, D. F. O. (2014). Efeito da temperatura, extração e embebição de sementes na germinação de Bactris maraja Mart. (Arecaceae). Revista Árvore, 38(5), 857-865. https://doi.org/10.1590/S0100-67622014000500010

Rufino, M. U. L., Medeiros-Costa, J. T., Silva, V.A., \& Andrade, L. H.C. (2008). Conhecimento e uso do ouricuri (Syagrus coronata) e do babaçu (Orbignya phalerata) em Buıque, PE, Brasil. Acta Botanica Brasilica, 22, 1141-1149. https://doi.org/10.1590/S0102-33062008000400025

Sanjeewani, B. L. G., Jayasuriya, K. M. G. G., Fernando, M. T. R., \& Damunupola, J. W. (2013). Storage and germination treatments for seeds of an ornamentally important palm, Livistona rotundifolia (Lam.) Mart. Journal of the National Science Foundation of Sri Lanka, 41, 273-277. https://doi.org/10.4038/jnsfsr. v41i4.6257

Silva, B. M. S., Cesarino, F., Lima, J. D., Pantoja, T. F., \& Môro, F. V. (2006). Germinação de sementes e emergência de plântulas de Oenocarpus minor Mart. (ARECACEAE). Revista Brasileira de Fruticultura, 28(2), 289-292. https://doi.org/10.1590/S0100-29452006000200030

Soares, J. S., Rosa, Y. B. C. J., Suzuki, R. M., Scalon, S. P. Q., \& Rosa Junior, E. J. (2012). Germinação assimbiótica e desenvolvimento de Dendrobium nobile Lindl. sob efeito de reguladores vegetais no tratamento pré-germinativo. Revista Brasileira de Plantas Medicinais, 14, 617-623. https://doi.org/10.1590/ S1516-05722012000400007

Yamashita, O. M., Guimaraes, S. C., \& Cavenaghi, A. L. (2011). Germinação das sementes de Conyza canadensis e Conyza bonariensis em função da qualidade de luz. Planta Daninha, 29(4), 737-743. https://doi.org/10.1590/S0100-83582011000400003

\section{Copyrights}

Copyright for this article is retained by the author(s), with first publication rights granted to the journal.

This is an open-access article distributed under the terms and conditions of the Creative Commons Attribution license (http://creativecommons.org/licenses/by/4.0/). 